\title{
NATIONAL REVIEW PANEL ON SCHOOL DESEGREGATION RESEARCH
}

$$
\text { 1977-1979 }
$$

Mark A. Chesler, Associate Professor of Sociology, University of Michigan; Executive Director, Community Resources, Ltd., Ann Arbor, Michigan. Formerly Project Director and Program Coordinator, Center for Research on the Utilization of Scientific Knowledge, Institute for Social Research, University of Michigan. Author, What Happened After You Desegregated the White School?, 22 NEw S. 10 (1967); Interaction and Teaching Alternatives in Desegregated Classrooms, in Racial Crisis In American Education (R. Green ed. 1969); Desegregation and School Crisis, 10 InTEgrated Educ. 54 (1972). Co-author, Voting Behavior and Attitudes Toward School Desegregation: A Study of Southern Negroes (Tuskegee Institute Report, 1967); Teacher Reactions to School Desegregation Preparation and Processes: A Case Study (Report, Institute for Social Research, 1968); Planning Educational Change III: Integrating the DeSegregated School (1970); When Northern Schools Desegregate, 4 Am. Educ. 2 (1968). Ph.D in Social Psychology, University of Michigan.

Robert L. Crain, Senior Social Scientist, The Rand Corporation. Formerly Associate Director, The Center for Urban Affairs, The Johns Hopkins University; Senior Study Director, The National Opinion Research Center; Director of Emergency School Assistance Program Study, Southern Schools: An Evaluation of the Effects of the Emergency School Assistance Program and of School Desegregation (National Opinion Research Center Report, 1973). Co-author, Political Strategies in Northern School Desegregation (1973); Discrimination, Personality and Achivement: A Survey of Northern Blacks (1972); The Politics of School Desegregation (1968); The Influence of High School Racial Composition on the College Attendance and Achievement Test Scores of Black Students (Report to the National Center for Education Statistics, 1978); Racial Tension in High Schools: Pushing the Survey Method Closer to Reality, ANTHRopology \& Educ. Q., May 1977, at 142. Ph.D in Sociology, University of Chicago.

Edgar G. Epps, Marshall Field IV Professor of Urban Education, The University of Chicago. Formerly Associate Editor of American Sociological Review; President, Association of Social and Behavioral Scientists. Co-author, Black 
Consciousness, Identity and Achievement: A Study of Students in Historically Black Colleges (1975). Author, City and Suburbs: Perspective on Interdistrict Desegregation Efforts, URBAN REV., Summer 1978, at 82; Educational Policy-Making: Implications for Urban Schools, 4 J. NeGRo Educ. 308 (1975); Impact of School Desegregation on Aspirations, Self-Concepts and Other Aspects of Personality, 39 Law \& Contemp. Prob., Spring 1975, at 300. Ph.D. in Sociology, Washington State University.

Willis D. Hawley, Associate Professor, Institute of Policy Sciences and Public Affairs, Duke University. Director, Center for Educational Policy, Duke University. Formerly Study Director, Education Study, President's Reorganization Project. Co-editor, The Courts, Social Science, and School Desegregation (1977). Author, The New Mythology of School Desegregation (Report, Center for Educational Policy, 1978); Teachers, Classrooms, and the Effects of School Desegregation on Effort in School (Report, Center for Educational Policy, 1976); Getting the Facts Straight About the Effects of School Desegregation, 36 Educ. LEADERSHIP 314 (1979). Co-author, On the Future Implementation of School Desegregation: Some Considerations, 39 Law \& Contemp. Prob., Spring 1975, at 412. Ph.D. in Political Science, University of California, Berkeley.

Betsy Levin, Professor of Law, Duke University School of Law. Member, HEW Civil Rights Reviewing Authority; member, National Council on Educational Research. Formerly Director of Education Studies, The Urban Institute; Special Assistant and White House Fellow to Hon. Arthur J. Goldberg, Ambassador to the U.N.; law clerk to Simon E. Sobeloff, U.S. Circuit Judge for the Court of Appeals for the Fourth Circuit. Co-editor, The Courts, Social Science, and School Desegregation (1977). Editor, Future Directions for School Finance Reform (1974). Author, The Courts as Educational Policymakers and Their Impact on Federal Programs (Rand Report, 1977); Current Trends in School Finance Reform Litigation: A Commentary, 1977 Duke L.J. 1099; School Desegregation Litigation in the Seventies and the Use of Social Science Evidence: An Annotated Guide, 39 Law \& Contemp. Prob., Winter 1975, at 50; Recent Developments in the Lau' of Equal Educational Opportunity, $4 \mathrm{~J}$. LAw \& Educ. 411 (1975). LL.B. Yale University School of Law.

John B. McConahay, Associate Director, Institute of Policy Sciences and Public Affairs, and Associate Professor of Policy Sciences and Psychology, Duke University. Formerly Director of Research, Educational Research Service. Author, Reactions to Busing in Louisville: Summary of Adult Opinions in 1976 and 1977 (Report, Institute of Policy Sciences, 1978). Co-Author, The Politics of Violence: The New Urban Blacks and the Watts Riot (1973) Psychol- 
ogy and America's Urban Dilemmas (1975); Is it the Buses or the Blacks? Self-Interest versus Symbolic Racism and Predictors of Opposition to Busing in Louisville (Report, Institute of Policy Sciences, 1977). Ph.D. in Social Psychology, University of California, Los Angeles.

James M. McPartland, Associate Professor of Social Relations, The Johns Hopkins University; Co-director and Principal Research Scientist, Center for Social Organization of Schools. Former consultant to U.S. Commission on Civil Rights. Co-editor, Violence in Schools: Perspectives, Programs and Positions (1977). Co-author, The Quality of School Life Scale: Administration and Technical Manual (1978); Discrimination, Segregation and Minority Social Mobility Processes, in Issues in Poverty Research (1979). Author, Strategies for Applying Formal Planning Tools to Program Decisions in Public Education, in Selected Readings in Quantitative Urban Analysis (1978). Ph.D. in Sociology, Johns Hopkins University.

Gary Orfield, Associate Professor of Political Science, University of Illinois. Consultant, American Political Science Association, Division of Educational Affairs and High School Curriculum Project. Author, Must We Bus? Segregation and National Policy (1978); The Reconstruction of Southern Education: The Schools and the 1964 Civil Rights ACt (1969); How to Make Desegregation Work: The Adaptation of Schools to their Newly-Integrated Student Bodies, 39 Law \& Contemp. Prob., Spring 1975, at 314, reprinted in 122 Cong. Rec. 21345 (1976); If Wishes Were Houses Then Busing Could Stop: Demographic Trends and Desegregation Policy, in School Desegregation in MetroPolitan Areas (National Institute of Education Conference Report, 1977), reprinted in 10 URB. Rev. 108 (1978); Congress, The President, and Anti-Busing Legislation, 1966-1974, 4 J. L. \& Educ. 81 (1975); School Integration and Its Academic Critics, Civ. Rights Dig., Summer 1973, at 2; Will Separate Be More Equal? 79 Integrated Educ. 3 (1976). Ph.D. in Political Science, University of Chicago.

Peter D. Roos, Director, Education Litigation, Mexican American Legal Defense and Educational Fund. Member, National Equal Educational Opportunity Committee. Formerly Senior Staff Attorney and Research Associate, Harvard University Center for Law and Education. Author, Issues in Desegregation Orders for Hispanos, in Desegration and Educational Concerns of the Hispanic Community, (1977); The Effect of Rodriguez on Other School Law Reform Litigation, 38 LAw \& ContemP. Prob., Winter-Spring 1974, at 566. Co-author, The Massachusetts Transitional Bilingual Education Act: Problems in the Classroom and Possible Legislative Responses, 19 INEQuAlity IN Educ. 38 (1975); 
Chicanos in the Schools: An Overview of the Problems and the Legal Remedies, 51 Notre Dame Law. 79 (1975). LL.B., Hastings College of the Law.

Christine H. Rossell, Assistant Professor, Department of Political Science, Boston University. Formerly consultant, Rand Corporation. Author, White Flight: Pros and Cons, Soc. PoL'y, November/December 1978, at 46; The Effect of School Integration on Community Integration, J. Educ., May 1978, at 46; School Desegragation and White Flight, 90 PoL. ScI. Q. 675 (1975-76). Ph.D. in Political Science, University of Southern California.

William L. Taylor, Director, Center for National Policy Review, Catholic University School of Law; Member of National Board and Executive Committee, Americans for Democratic Action; Executive Committee, Leadership Conference on Civil Rights. Formerly Staff Director, U.S. Commission on Civil Rights; Secretary, President's Sub-Cabinet Group on Civil Rights. Author, Hanging Together: Equality in an Urban Nation (1971); Legal Issues in School Desegregation, 19 Howard L.J. 20 (1975); The Supreme Court and Urban Reality: A Tactical Analysis of Milliken v. Bradley, 21 Wayne L. Rev. 751, (1975); Busing: Realities and Evasions, 19 Dissent 586 (1972); Metropolitan-Wide Desegregaion, 11 Inequality in Educ., March 1972, at 45, LL.B., Yale University School of Law.

Mark G. Yudof, John S. Redditt Professor of Law, University of Texas School of Law; Chairman, National Study Group on Legal and Governmental Studies, National Institute of Education. Formerly Associate General Counsel of the Commission of the American Bar Association to Study the Federal Trade Commission; Research Associate and Senior Staff Attorney, Harvard University Center for Law and Education; law clerk to Robert A. Ainsworth, U.S. Circuit Judge for the Court of Appeals for the Fifth Circuit. Co-author, Eductional Policy and the Law (1974). Author, International Human Rights and School Desegregation in the United States (UNESCO Report, 1978); Suspension and Expulsion of Black Students From the Public Schools: Academic Capital Punishment and the Constitution, 39 Law \& Contemp. Рrob., Spring 1975, at 374. LL.B., University of Pennsylvania School of Law. 